\title{
Enhancing Quality Assurance through Harmonization of Business Education Curricular in Nigerian Universities and Avoiding Functional Dilemmas of Expectations and Realities
}

\author{
*Amahi Fidelis U, Ogben Felix \\ College of Education, Agbor Delta State, Nigeria \\ *fidelis_amahi@yahoo.com
}

\begin{abstract}
The paper focuses on enhancing quality through the harmonization of business education curricular across the globe and Nigerian universities in particular. 35 graduate students from three tertiary institutions were randomly selected and 15 lecturers in business education were the sample subjects. The survey method was used to determine the effects of lack of uniformity in business education curriculum at graduate level the mean and standard deviation were used to analyze the items. The t-test statistics method was also used. It was found out that there was lack of uniformity in the curricula of business education at graduate level among other things. The paper recommends that supervisory authorities should harmonize the curricula of business education to ensure uniformity in tertiary institutions particularly at graduate level and to enhance and ensure quality of the programme. It also recommends that $80 \%$ of the course content in the core option areas be incorporated into the curriculum to enhance performance and learning outcome and avoid functional dilemma of expectation and realities.
\end{abstract}

Keywords: Quality, harmonization, functional dilemma of expectations

\section{Introduction}

Education is one of the basic necessities of life without which no meaningful progress can be achieved in any human endeavor. As has been stated that it is a major transformation tool, educational institutions are set up by government, individuals and agencies to train, educate and develop both youth and adults to meet the needs, interest and aspirations of the individuals and the society (FGN, 2004). One of the national educational goals which derive from the philosophy of education as FGN (2004) notes is the acquisition of appropriates skills and the development of mental, physical and social abilities and competencies as equipment for the individual to live and contribute to the development of the society. In consequence, the quality of instruction at all levels has to be oriented towards inculcating amongst other values, the acquisition of competencies necessary for self-reliance. This responsibility was hitherto carried out by teachers who are managers in the teaching-learning process thereby making them the critical success factor in the imparting of knowledge, skills, aptitude and competencies to the recipients. The national policy on education as FGN (2004) reveals is that Business education as an occupational area of Technical and vocational education training,(TVET)) which process involves "in addition to general education, the study of technology and related science and the acquisition of practical skills, attitudes, understanding and knowledge relating to occupation in various sectors of economic and social life. However, the skills, knowledge and values would not be attained if the curriculum is not developed and enriched to elicit the right learning outcomes which are the expectations of the society. The acquisition of these skill, aptitudes, knowledge and understanding goes with some degree of quality. What then is assurance?

\section{The Concept of Quality Assurance}

With increasing desires and access to education and the acquisition of high level of qualification the relevance and quality of training become significant. As Webster new international Dictionary (1986) defines quality as the degree of excellence, degree of conformity to standard, an attribute that has been obtained after a certain level is attained. Quality as maduewesi in Ojukwu and Osuagwu (2008) defines is "a multifaceted issue which encompasses how learning is organized and managed, what the content of learning is, what level of learning is achieved, what it leads to in terms of outcomes, and what goes on in the learning environment". Quality in 
education is the totality of the characteristics of learning programmes and of its providers through which the expectation of the beneficiaries and the quality standard are met as has been shown (Education Law, 2006). Quality assurance $(\mathrm{QA})$ is the totality of the principles, methodologies, actions, measures and instrument through which quality is assured at system and providers level. Quality assurance originated during industrial revolution when production was large scale and it tended to ensure that quality production was manufactured. This assertion as corroborated by Allais (2009) is that quality assurance has its root in large scales manufacturing and refers to systems, which are developed to monitor all processes that are part of the work. However, there are five terms which are often used as substitutes for one another but have slightly different meanings from the scientific point of views. They are quality management, quality assurances, quality control, quality assessment and quality improvement. Quality management is an umbrella term encompassing the specific notions of the others. QA aims to avoid unfavourable development and so prevents poor quality. Quality control is oriented towards the collection of information to correct unfavourable development and thus is a necessary precondition to quality assurance. Quality assessment goes beyond and is about the measurement of outputs and outcomes based on predefined objectives for quality while quality improvement is the continuous change and improvement of process and performance to better the quality objective (Cedefop, 2009).

In business teacher's education, quality is directly related to the achievements of the learning outcomes (knowledge, skills and competence achieved at the end of the learning process) that fulfill the key stakeholder's expectations. Little wonder why the school curriculum expresses the society expectation of the school system, thus it must be designed to meet the changing needs of the society. It is thus the offering of socially valued knowledge, skills and attitude made available to students through a variety of learning experience arranged during the time they were at school, college and university. The key stakeholders in the education sector are government, students, teachers, parents, employers and community in general. For quality to be assured in business teachers education, so many issues are involved, ranging from how good and efficient the teachers are, how adequate and accessible the facilities and materials needed for effective teaching and learning are, and how prepared the graduates are, in meeting the challenges in the society and how relevant is the curriculum of the students to the needs of the changing society. Off all these, the two most important are the quality of teachers and the relevance of the curriculum used for the training of the teachers. The success of any organization depends on the quality and efficiency of its personnel who carry out their responsibilities in the most effective manner.

As Crews and Dickson in Ndinechi (2001) note that the teacher of the curriculum and the success of any curriculum directly related to the teacher and therefore business teachers should be exposed to a wide variety of teaching options. According to him the basis of determining the curriculum of Business Teacher Education program should be the dual purpose of business education which is to provide instruction both FOR and ABOUT business. Therefore the needs of the business education teachers in terms of teaching as well as content competencies must be the determiner of the business teacher's education programme. As This lewaite in Ndinechi (2001) opines that one major reform which should be incorporated in business teacher education curriculum is to get away from the narrow confines of the term, business education with its typewriting, shorthand, bookkeeping, how-to-do-it skills only concept and think of educating teachings for broad aspects of business. He further said that business teachers cannot hope to effectively train students for positions in business when they themselves have had insufficient training in modern business subjects. Afe in Arubaye (2003) opine that quality education is impossible without teachers. They constitute the most vital factor of any educational system as upon their quality, the effectiveness of all educational arrangement must chiefly depend. As Aina in Akpotohwo (2005) and corroborating with Ndinechi (2001) observes that the preparation of business education teachers at all levels must be a major concern to us as several aspects of our business education curricula which are dedicated to the past, no longer fulfill our needs today anymore.

Efforts at Unifying Curriculum of Business Education: Before the early 1980's training for business education was largely the responsibility of private concerns and there was no uniform curriculum. It is sad to note that safe for little efforts made at the University of Nigeria, Nsukka and Ahmadu Bello University Zaria in the early 1960 s and 1970s business teachers education was relatively a newcomer in the Nigerian higher teacher 
education scene as asserted by (Ekpeyong, 1993). However, owing to the acute shortage of professionally qualified business teachers to implement the new JSS curriculum, many colleges of education then introduced courses in business teacher education and were affiliated to universities of their choice which assisted in the design of their curricula for instruction. In 1985 the national council on education (NCE) held a meet at Maiduguri in response to the recommendation of the Joint consultation committee on education (JCC) the national board for technical education (NBTE) came out with a unified national curriculum for business education for NCE awarding institutions. But the curriculum developed was limited in scope and due to the fact that the function was not reflected in the Act establishing NBTE, there arose a need for the establishment of a body similar to NUC and NBTE to coordinate the affairs resulting to the education and training of teacher at the NCE level. So in an attempt to ensure uniformity and standard in the teacher education programs throughout the federation, the central government set up the national commission for colleges of Education,, NCCE in 1989 by decree No.3 as the third leg of the tripod of excellence in the supervision of tertiary education in Nigeria and was charged, among others with the responsibility to lay down minimum standard for all programs of teacher education and accredit their courses, certificates and academic awards and approve guidelines for accreditation.

Statement of the Problem: With the establishment of the supervisory bodies like national universities commission, NUC national commission for colleges of education NCCE, the curricula of programmes of study are expected to be same throughout the entire nation to ensure uniformity in standards. apart from the curriculum of business education at the college of education which are same all over the country, the curricula of business education at the undergraduate and graduate levels of our universities seem not to be the same as each university appears to mount her programme and develops the curriculum in line with the perception of the developers thereby making the program to lack uniformity. Certificates awarded/issued are not uniform. Some universities award B.Ed business education; B.sc(Ed) business education (accounting); B.Ed vocational and Technical Education; M.Ed business education; M.Sc business education; M.ED vocational and technical education (business education). A look at application of business education graduates seeking for jobs reveals that business education has not arrived in terms of certificate as it leaves the officers short listing with doubt and bias as to who qualifies for what. This is because some of the certificates presented do not indicate specific areas of specialization and therefore an indication that all may not be well in business education and there may be lack of uniformity and harmonization of programmes at tertiary level.

Purpose of Study: The major purposes of the study are to:

- Determine whether there is difference in the curricula of business education program at graduate levels in Nigerian universities to justify the difference in certificates awarded

- To determine if the curricula of business education at graduate level have imparted on the lecturers' quality and ability to deliver their lectures effectively

- To determine whether the graduates of business education are satisfied with the certificates awarded.

\section{Research Questions}

- To guide the study, the following research questions were formulated

- Do the curricula of business education at graduate level of Nigerian universities differ and lack uniformity?

- To what extent does lack of uniformity of curricula of business education at graduate level affect the quality assurance of lecturers and learning outcomes?

- How relevant is the curricula of business education at graduate level to the role of teaching core accounting and secretarial courses

- To what extent does the non indication of the core area of specialization on the certificates issued in business education affect job prospect and allocation of courses to lecturers?

\section{Hypotheses}

- There is no significant difference in the mean responses of graduate students and lecturers in business education on the lack of uniformity of business education curricula at graduate level of Nigerian universities. 
- There is no significant difference in the mean responses of graduate students and lecturers in business education on the effect of lack of uniformity in curricula of business education at graduate level on quality assurance.

\section{Methodology}

The survey method was used for the study in determining the effect of lack of uniformity of curricula of business education at graduate level of Nigerian universities on the quality assurance in terms of learning outcomes and effectiveness in the delivery of lectures by lecturers. The samples of the study was 50 made up of 35 graduate students of business education randomly selected from the university of Benin Benin-city, university of Nigeria Nsukka and Nnamdi Azikwe University Awka and 15 lecturers at the College of Education Agbor Warri and Asaba. The questionnaire was in three sections. Section A had items 1-7 which sought information on the curricula in relation to whether they are uniform in content, adequate in scope, relevant to the core option areas in business education and whether the certificate awarded were not related to the lack of uniformity in curricular. Section B had items 8-15 which sought information on the extent to which lack of uniformity in curricula affect quality assurance of lecturers in terms of learning outcomes and effectiveness in the delivery of lectures. Section C required respondents to indicate course offered at the graduate level and the certificate awarded on completion of the programme. The questionnaire was structured on a 4 point rating scale of strongly agreed (SA), Agreed (A), Disagreed (D) and strongly disagreed (SD). This was validated by two chief lecturers in the areas. The reliability coefficient of 0.86 was used to determine the internal consistency of the questionnaire items. Mean and standard deviation were used for the item analysis. The hypotheses were tested using t-test and 2.50 was the minimum mean indicating agreement.

\section{Results and Discussion}

Table 1: Respondent means and Std Dev rating on the extent to which curriculum lack uniformity

\begin{tabular}{|c|c|c|c|c|c|}
\hline $\mathrm{S} / \mathrm{N}$ & & $\mathrm{X}$ & SD & $\mathrm{X}$ & SD \\
\hline 1 & $\begin{array}{l}\text { Curricula business education at graduate level on Nigerian universities } \\
\text { lack of uniformity }\end{array}$ & 3.1 & 1.6 & 3.0 & 1.3 \\
\hline 2 & $\begin{array}{l}\text { The curriculum of business education are loaded with courses other than } \\
\text { accounting and office information courses }\end{array}$ & 3.7 & 1.4 & 3.3 & 1.6 \\
\hline 3 & $\begin{array}{l}\text { The composition of the courses for business education graduate students } \\
\text { is not adequate }\end{array}$ & 2.9 & 1.6 & 2.8 & 1.3 \\
\hline 4 & $\begin{array}{l}\text { There is no specialization in business education at graduate level in } \\
\text { some universities }\end{array}$ & 3.1 & 1.6 & 3.0 & 1.2 \\
\hline \multirow[t]{2}{*}{5} & Courses in secretarial (office technology) option of business education at & 3.1 & 1.6 & 3.5 & 1.0 \\
\hline & graduate level not developed & 2.7 & 1.4 & 3.00 & 1.2 \\
\hline 6 & $\begin{array}{l}\text { The curricula of business education of most universities at graduate level } \\
\text { for accounting potion have not more than two accounting courses }\end{array}$ & 2.7 & 1.4 & 1.6 & 1.4 \\
\hline \multirow[t]{2}{*}{7} & The certificate awarded to graduate of business education vary & 3.8 & 1.3 & 3.2 & 1.0 \\
\hline & grand means/standard deviation & 3.2 & 1.5 & 2.9 & 1.2 \\
\hline
\end{tabular}

Table 1, above shows that the lecturers and graduates students of business education department agreed that there is lack of uniformity in the curricular of business education with the grand mean 3.2 and 2.9 respectively. The standard deviation of 1.5 and 1.2 are homogenous in agreement within the group. Except for item 6 where the lecturers disagreed that the curricula of business education accounting option do not have more than two accounting course, other items mean response by both group of respondents were above the decision mean of 2.50 . 
Hypothesis one: There is no significant difference between the mean response of graduate students and lecturers in business education on the lack of uniformity of curricula of business education at graduate levels of Nigeria universities.

Table 2: Mean and SD of graduate students and lecturers response on lack of uniformity in the curricula of business education at graduate level

\begin{tabular}{llllllll}
\hline & $\mathbf{X}$ & $\begin{array}{l}\text { Standard } \\
\text { deviation }\end{array}$ & $\mathbf{N}$ & DF & E-call & t-Critical & Decision \\
\hline $\begin{array}{l}\text { Lecturer } \\
\text { graduate }\end{array}$ & 2.9 & 1.2 & 1.5 & & & & \\
students & 3.2 & 1.5 & 35 & 48 & 0.75 & 2.021 & accepted \\
\hline
\end{tabular}

Table 2 , show that $\mathrm{t}$-critical is 2.021 while $\mathrm{t}$-calculated is 0.75 . Since the $\mathrm{t}$-critical is higher than $\mathrm{t}$-calculated at 0.05 alpha levels the null hypothesis of no significance difference in the mean response of lecturers and graduate students on lack of uniformity in curricula of business education retained.

Table 3: Respondents mean and standard rating on the effect of lack of uniformity in curricula on quality assurance of lectures and learning outcomes

\begin{tabular}{|c|c|c|c|c|c|}
\hline 8 & $\begin{array}{l}\text { Lack of uniformity in the curricula of business education affects quality } \\
\text { of lectures and learning outcome }\end{array}$ & 3.7 & 1.3 & 3.9 & 1.2 \\
\hline 9 & $\begin{array}{l}\text { Curriculum of business education program of graduate students with } \\
\text { courses in core business area of accounting and secretarial affect the } \\
\text { quality of lectures in these courses. }\end{array}$ & 3.5 & 1.5 & 3.6 & 1.3 \\
\hline 10 & $\begin{array}{l}\text { The curriculum of business education for graduates students without } \\
\text { courses in the option are is not too relevant for effective teaching and } \\
\text { learning }\end{array}$ & 3.6 & 1.6 & 3.5 & 1.1 \\
\hline 11 & $\begin{array}{l}\text { Business education certificate issued on graduation without indicating } \\
\text { areas of specialization affect negatively job prospects and short listing } \\
\text { for job interview }\end{array}$ & 3.5 & 1.5 & 2.3 & 1.4 \\
\hline 12 & $\begin{array}{l}\text { Business education certificate issued without indicating areas of } \\
\text { specialization affect negatively the allocation of courses to lectures }\end{array}$ & 2.9 & 1.4 & 3.0 & 1.5 \\
\hline 13 & $\begin{array}{l}\text { Some business educators are indifferent on the areas of specialization in } \\
\text { business education }\end{array}$ & 2.9 & 1.6 & 2.9 & 1.6 \\
\hline 14 & $\begin{array}{l}\text { Some business educators supposedly in core areas of specialization } \\
\text { avoid teaching some courses for obvious reasons of not having the } \\
\text { adequate knowledge in them. }\end{array}$ & 2.5 & 1.3 & 3.5 & 1.1 \\
\hline 15 & $\begin{array}{l}\text { Harmonization of curricula of business education of graduate level } \\
\text { would improve the quality of lectures and learning outcomes and } \\
\text { enhance quality assurance }\end{array}$ & 3.9 & 1.4 & 2.1 & 1.3 \\
\hline
\end{tabular}

Table 3: above shows that both lecturers and graduate students agreed that lack of uniformity in the curriculum of business education for graduates students affect quality assurance and that curricular without concentration in core areas of specialization are not too relevant to recipients. All the mean responses by both groups of respondents were above the decision mean of 2.50 .

Hypothesis Two: There is no significant difference in the mean response of graduate students and lecturers in business education on the effects of lack of uniformity of curricula of business education at graduate level on quality assurance. 
Table 4: Mean and SD of graduate students and lecturer responses on effect of lack of uniformity in curricula of business education on quality assurance

\begin{tabular}{llllllll}
\hline & $\mathbf{X}$ & $\begin{array}{l}\text { standard } \\
\text { deviation }\end{array}$ & $\mathbf{N}$ & DF & t-cal & t-Critical & Decision \\
\hline $\begin{array}{l}\text { lecturer } \\
\text { graduate }\end{array}$ & 3.1 & 1.3 & 15 & & & & \\
students & 3.2 & 1.4 & 35 & 48 & 0.24 & 2.021 & retained \\
\hline
\end{tabular}

In the above table the t-calculated value of 0.24 is lower than the t-critical value of 2.021 at 0.05 level of significance. Therefore the null hypothesis is retained.

Discussion: There is no uniformity in the curricula of business education of graduate students in the Nigeria universities. This is supported by the courses offered by the graduate students at the universities sampled. A critical look at the courses offered at this level shows that not much concerned knowledge for and about business. The curriculum was loaded with courses other than accounting, secretarial, marketing and business administration courses and therefore not relevant to the present day. It was also found out that the certificates of some universities do not indicate the area of specialization. Further findings included that lecturers exposed to the curriculum without courses in core option areas, avoid teaching courses in core option areas for obvious reasons of not having adequate knowledge in them and therefore, it affects the effective allocation of courses to lecturers. Short listing of applicants for job vacancies in business education where core option areas are needed becomes difficult as some certificate do not indicate area of specialization. Secretarial education courses are not developed nor run in some universities at this level.

\section{Conclusion}

Based on the findings the following conclusions have been drawn since there is lack of uniformity in curricula of graduate students, quality assurance is being affected as there exits different knowledge background and notions/believe about what business education is all about. There would be no effective teaching of students in the core option areas as some of the lecturers do not have deeper knowledge in the area arising from the lack of exposure to the core option area and that the certificates are worded differently without indicating areas of specialization.

Recommendations: NUC in collaboration with the association of business education of Nigeria ABEN should harmonize the curricula of business education at tertiary institutions. The certificates awarded should be uniform in wordings and should reflect the option areas of business education. The curriculum should include $80 \%$ of the course in core options areas to enable the beneficiaries adequately have the knowledge and ability to impact the knowledge for and about business to students and to meeting the expectations of the society in order to avoid functional dilemmas of the expectations and realities.

\section{References}

Akpotohwo, F. C. (2005). NCE Business Teacher Education Assessment of the NCCE minimum standards for business education ,2002.M.Sc business education dissertation at Nnamdi Azikiwe University, Awka.

Allais, S. M. (2009). Quality assurance in education: Issues in education policy .Number 5 Johannesburg Centre of education policy development.

Arubaye, E. O. (2003). Improvement of instruction and teacher effectiveness in tertiary institutions: Are students ratings reliable and valid ?Being a fourth inaugural lecture at Delta State University, Abraka.22-27

Education law. (2006). Government emergency ordinance no $.75 / 2005$ regarding the quality assurance of education

Ekpeyong, L. E. (1993). Trends in business Teacher Education Curriculum design: An analysis of the NBTE and NCCE models in Anyakoha, E.U and Osuala E.C (eds). Vocational/Technical Education and Technological Growth.pp(134-141) Nsukka: Nigerian Vocational Association 
European Centre for the development of vocational training union cedefop. (2009). Accreditation and quality assurance in vocational education and training. Luxembourg: Publications Office of the European Union

Federal Government Nigeria FGN. (2004). National Policy on Education (revised) Lagos: NERDC

Ndinechi, G. I. (2001). The purpose and function of business education. Nigeria Association of Business Educations. Annual Conference lead paper. Oko. Anambra 10-15

Ojukwu, U. A. \& Osuagwu, P. N. (2008). School base assessment (SBA): An Instrument for quality assurance in primary basic education. Nigeria Journal of curriculum studies (Special Edition).

Webster New International Dictionary (1986)

Courses Offered at the Graduate Level of Business Education

M.Ed Business Education (UNIBEN)

M.Sc Business Education

(UNIZIK)

Edu 801-Research Method in Edu.

Bed 631 Curr.

Dev

Ved 803-Mgt of Voc. Edu/

Bed 632 Instr.

strategy

Ved 806- Curriculum planning

Bed 623 Evalu. In Voc.

\& Tech.

Bus 752-Human resource Management

Bed 601

Contemp. issues

Edu 802- Educational Statistic

Epc 843- instructional Comm. and Tech

Bus 611 Admin. theory

Accounting

Epc 834- vocational guidance

Ved 81-Advance Admin. Mgt

Acc 711-Accounting for Managers

statistics

Ved 807-Advert and comsumer Edu

Acc $601 \mathrm{Mgt}$

Thesis

Ved 899- Project

M.Ed Voc. \&Tech in UNN

Vte 501- theories of voc. Edu

503- Empirical methods

504-Policy issues

505 Admin and supervisor

506-Vocamtric for Voc \& tech

510- occupational guidance

542-traning in govt accounting

507-statistic

502-Seminar in the Edu

SOURCE: STUDENTS' HANDBOOK

\author{
511- Curriculum development \\ 513-Ednal facilities planning \\ 515 Evaluation in Voc \& tech \\ 590-project \\ 535-fundation of Bus. Edu \\ 541- Marketing and cons. Edu \\ 543-Issues in Marketing
}

